\title{
Biological performance of the predatory mite Neoseiulus idaeus (Phytoseiidae): a candidate for the control of tetranychid mites in Brazilian soybean crops
}

\author{
M. B. Reichert ${ }^{*}$, M. Toldi ${ }^{a}$, P. A. Rode ${ }^{a}$, J. J. Ferla ${ }^{a}$ and N. J. Ferla ${ }^{a}$ \\ a'Laboratório de Acarologia, Centro Universitário UNIVATES, Av. Avelino Tallini, 171, Bairro Universitário, \\ CEP 95900-000, Lajeado, RS, Brazil \\ *e-mail marliza@cfjl.com.br
}

Received: September 21, 2015 - Accepted: January 14, 2016 - Distributed: May 31, 2017

(With 3 figures)

\begin{abstract}
The soybean (Glycine max (L.): Fabaceae) is considered the most important agricultural crop in Brazil. Phytophagous tetranychid mites as Mononychellus planki McGregor, Tetranychus ludeni Zacher and T. urticae Koch have been considered pest in soybean crops. Neoseiulus idaeus Denmark \& Muma (Phytoseiidae) is a predatory mite of T. ludeni and T. urticae. The aim of the present study was to evaluate the biological performance of $N$. idaeus when fed on T. urticae, T. ludeni and M. planki, coming from the Northwest region of Rio Grande do Sul state, Brazil. The study was conducted in the laboratory with individual predators supplied with different preys. The mean duration (days) of $N$. idaeus egg-adult

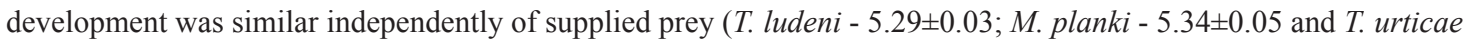
- $5.23 \pm 0.03$ days). Female viability was $90 \%$ when fed on M. planki and $100 \%$ when fed on T. ludeni and T. urticae. Mean fecundity of $N$. idaeus was lower when fed on M. planki (4.6 \pm 1.58 eggs/female) and higher when fed on T. ludeni (21.8 \pm 3.22 ) and T. urticae (26.2 \pm 2.41$)$. The mean generation time (T) was lower when $N$. idaeus fed on M. planki than when fed on T. ludeni and T. urticae. The net reproductive rate $\left(\mathrm{R}_{\mathrm{o}}\right)$ was $4.42 \pm 0.49$ on M. planki, $17.77 \pm 0.55$ on T. ludeni and $20.59 \pm 0.48$ on T. urticae. The innate capacity for increase $\left(\mathrm{r}_{\mathrm{m}}\right)$ was lower when $N$. idaeus was fed on M. planki (0.09) and higher when such predator was fed on T. ludeni ( 0.20$)$ and $T$. urticae ( 0.22 females/females/day). These results demonstrated that $N$. idaeus is able to reach the complete development feeding on all the three tetranychid species. Mononychellus planki demonstrated to provide a sub-optimal diet if compared to T. ludeni and T. urticae.
\end{abstract}

Keywords: biological control, life table, Tetranychus urticae, Tetranychus ludeni.

\section{Desempenho biológico do ácaro predador Neoseiulus idaeus (Phytoseiidae): um candidato no controle de ácaros tetraniquídeos em soja brasileira}

\section{Resumo}

Soja (Glycine max (L.): Fabaceae) é a mais importante cultura agrícola brasileira. Tetraniquídeos fitófagos são pragas na cultura, Mononychellus planki McGregor, Tetranychus ludeni Zacher e T. urticae Koch. Neoseiulus idaeus Denmark \& Muma (Phytoseiidae) é o ácaro predador de T. ludeni e T. urticae. Este estudo teve como objetivo avaliar o desempenho biológico de $N$. idaeus quando alimentado com $T$. urticae, T. ludeni e M. planki da região noroeste do Rio Grande do Sul, Brasil. O estudo foi realizado em laboratório com predadores individualizados com diferentes presas. A duração média (dias) de $N$. idaeus desenvolvimento ovo-adulto foi semelhante independentemente da presa fornecida (T. ludeni $-5.29 \pm 0.03$; M. planki $-5.34 \pm 0.05$ e T. urticae $-5.23 \pm 0.03$ dias). Viabilidade feminina foi de 90\% quando alimentados com M. planki e 100\% em T. ludeni e T. urticae. Fecundidade de N. idaeus foi menor com M. planki (4.6 \pm 1.58 ovos / fêmea) e maior com T. ludeni e T. urticae, $21.8 \pm 3.22$ e $26.2 \pm 2.41$, respectivamente. $\mathrm{O}$ tempo médio de uma geração (T) foi menor quando $N$. idaeus alimentados com M. planki do que quando em T. ludeni e T. urticae. A taxa líquida de reprodução (Ro) foi de $4.42 \pm 0.49 \mathrm{em}$ M. planki, $17.77 \pm 0.55 \mathrm{em}$ T. ludeni e $20.59 \pm 0.48$ no T. urticae. A capacidade inata de aumento (rm) foi menor em M. planki (0.09) e maior quando alimentados com T. ludeni ( 0.20$)$ e T. urticae ( 0.22 fềmeas / fêmea / dia). Estes resultados demonstraram que $N$. idaeus é capaz de utilizar e desenvolver em todas as três espécies de tetraniquídeos. Mononychellus planki demonstrou ser a presa menos adequada para este predador do que T. urticae e T. ludeni.

Palavras-chave: controle biológico, tabela de vida, Tetranychus urticae, Tetranychus ludeni. 


\section{Introduction}

The soybean (Glycine $\max (\mathrm{L}$.): Fabaceae) is the most important agricultural crop in Brazil, since the country produced 86 tons during 2013 and 2014, being considered the second largest world soybean producer. Soybean production is widely distributed in Brazilian territory. However, the largest acreages are located in the Midwest and South regions; especially in the states of Mato Grosso, Paraná and Rio Grande do Sul. During 2013 and 2014, Rio Grande do Sul produced approximately twelve millions of tons. Such amount represent $15 \%$ of the Brazilian soybean production (CONAB, 2014).

This crop is susceptible to herbivorous attacks, which may cause substantial damage and production losses. Despite several animals might affect soybean crops, a special group responsible to such damage are phytophagous tetranychids mites. This affirmation is reinforced by recent studies that have been reporting high populations of tetranychids mites species (Mononychellus planki McGregor, Tetranychus desertorum Banks, T. gigas Pritchard \& Baker, T. ludeni Zacher and T. urticae Koch) in soybean crops (Guedes et al., 2007; Reichert et al., 2014; Rezende et al., 2014; Roggia et al., 2008).

Tetranychids may cause damage to several plants species (Bolland et al., 1998; Silva et al., 2009). These mites feed on parenchyma and extract the cell contends, causing a reduction of the plant photosynthetic capacity, affecting directly the grain production (Moraes and Flechtmann, 2008). Under temperatures around $30^{\circ} \mathrm{C}$, T. ludeni increase drastically its reproduction and fecundity rates, leading to highly economic damage in regions with such climate (Silva, 2002). Despite its growing population, until recently $M$. planki was not mentioned as a mite of economic importance (Moraes and Flechtmann, 2008). However, currently such mite specie has been considered the most frequent and abundant in soybean crops (Reichert et al., 2014; Rezende et al., 2014).

Predatory mites of Iolinidae, Phytoseiidae and Stigmaeidae have been commonly associated to Brazilian soybean crop (Reichert et al., 2014; Rezende et al., 2014). However, Phytoseiid are the most common and abundant mites in such crop. Considered as generalist predators, this mite family may feed on spider mites, insects, nematodes, fungus, pollen and plant exudates (McMurtry et al., 2013; Marafeli et al., 2014), but rarely on vegetable tissues (Magalhães and Bakker, 2002; Sengonca et al., 2004). Several members of this mite family have been considered of great importance in applied biological control of mites and thrips in greenhouse crops production (Zhang, 2003) and orchards (Moraes et al., 2004).

Phytoseiid mites of the genus Neoseiulus have been commonly observed on soybean crops (Reichert et al., 2014; Rezende et al., 2014). Neoseiulus anonymus Chant \& Baker, $N$. californicus McGregor and $N$. idaeus Denmark \& Muma are common mite species in Rio Grande do Sul State (Reichert et al., 2014). However, available information about this mite family in soybean crops of Rio Grande do Sul State is scarce. Recently, Reichert et al. (2014) mentioned $N$. idaeus as the most common mite specie in Rio Grande do Sul state soybean crops. Neoseiulus idaeus is reported as the main predator associated to Mononychellus tanajoa (Bondar) (green cassava mite) in northeast of Brazil (Moraes et al., 1990). In cassava crops such predator mite demonstrated capacity to control T. urticae population (Moraes et al., 1994).

Phytoseiid are commonly observed in association with phytophagous mites in annual, perennial and native vegetation (Ferla and Moraes, 2002). However, studies regarding the biological capacity of $N$. idaeus to control phytophagous mites are scarce in South Brazil. In this way, the present study attempts to investigate the biological performance of $N$. idaeus when fed on T. urticae, T. ludeni and $M$. planki. This study might help to identify a natural enemy that could be used in applied biological control of phytophagous tetranychids mites in soybean crops from Northwest region of Rio Grande do Sul state, Brazil.

\section{Material and Methods}

\subsection{Stock colony}

The present study was carried out at the Acarology Laboratory of UNIVATES, Lajeado, Rio Grande do Sul State, Brazil. The predator mite $N$. idaeus was collected from soybean plant leaves at a commercial production site located in Northwest of Rio Grande do Sul State. These mites have been maintained in laboratory on bean plant (Phaseoulus vulgaris L.), and fed on T. urticae coming from strawberry, for two months before the beginning of the studies. M. planki, T. ludeni and T. urticae also were maintained on bean plants in laboratory. The rearing stocks were conducted in a germination chamber under $25 \pm 1^{\circ} \mathrm{C}$ with 12 -hour photophase and $70 \pm 5 \%$ relative humidity.

\subsection{Experimental design}

The biological study was carried out with 90 predator eggs individualized in arenas with different prey. Additionally, 30 eggs for each food type were added. In each arena, we added 15 specimens of different developmental stages of T. ludeni, M. planki and T. urticae. The experiment started with the addition of three $N$. idaeus females from the rearing stock in each arena. They were removed four hours later, leaving just one predatory mite egg/arena.

The immature stages have been observed at $7,11,15$ and 19 hours respectively. In such observations, the duration of life stages was checked. During the adult stage, females were maintained mated with the rearing stock males and the evaluations, to determine the number of eggs laid as well as the survival rate, were performed once a day, at 11 hours. With the aim of determine F1 sex ratio, the laid eggs were collected and transferred to other arenas. The obtained data were compared by Tukey test at a $5 \%$ significance level, with the use of Bioestat 5.0 software (Ayres et al., 2007). The arenas have been maintained in the same environment conditions presented in the rearing stock. 
The data obtained in the study were organized for life table calculations (Silveira et al., 1976). Subsequently, the values regarding to the reproductive rate net $\left(R_{o}=\Sigma m x . l x-m x\right.$ : total eggs/females number; $l x$ : specimens alive/specimens total $)$, generation time $(\mathrm{T}=\mathrm{mx} . \mathrm{lx} . \mathrm{x} / \mathrm{mx} . \mathrm{lx} \Sigma)$, innate capacity for increase $\left(r_{m}=\log R_{o} / T .0 .4343\right)$, and finite increase rate $\left(\lambda=\operatorname{antilog} r_{m}\right)$ were calculated. The mean and standard deviation of each life table parameter was calculated using Bootstrap analysis (Efron and Tibshirani, 1994). A total of thirty random choices, with replacement at every drawn number, were made. In this way, mean and standard deviation could be calculated with the random values.

\section{Results}

The evaluation of $N$. idaeus strain demonstrate that, when fed on M. planki, T. ludeni and T. urticae, such predator mite may reach the adult phase and lay eggs. These results were similar when $N$. idaeus was fed on T. ludeni and T. urticae and lower, especially in the adult phase, when $N$. idaeus was fed on $M$. planki.

The mean duration (days) of females egg-adult phase was similar in the three prey evaluated (Table 1). The viability was $90 \%$ when fed on $M$. planki and $100 \%$ when fed on T. ludeni and T. urticae. The mean duration of incubation phase (days), was longer when the predator was fed on T. ludeni and shorter when fed on M. planki. The duration of larvae and deutonymph stages was similar when the predator fed on all the preys. However, the protonymph stage was longer when the predator was fed on M. planki. For males, egg-adult phase was longer on T. ludeni and lower on T. urticae.

The mean fertility of $N$. idaeus was lower when fed on $M$. planki (4.6 \pm 1.58 eggs/female) and higher when fed on T. ludeni and T. urticae (21.8 \pm 3.32 and 26.2 \pm 2.4$)$.

The mean time duration (days) of pre-oviposition was longer when $N$. idaeus was fed on $M$. planki, while fertility, oviposition and longevity of females was lower (Table 2). Generally, when T. ludeni and T. urticae have been offered as prey, the adult phases were longer.

The sex ratio in the first generation of the predator was 0.80 . The mean generation time $(\mathrm{T})$ was lower when $N$. idaeus was fed on M. planki than when fed on T. ludeni or T. urticae (Table 3$)$. The net reproductive rate $\left(\mathrm{R}_{\mathrm{o}}\right)$ and innate capacity for increase $\left(\mathrm{r}_{\mathrm{m}}\right)$ were lower when $N$. idaeus

Table 1. Duration in days (mean $\pm \mathrm{SE}$ ) of immature stages of Neoseiulus idaeus feeding on Mononychellus planki, Tetranychus ludeni and Tetranychus urticae, at $28 \pm 1^{\circ} \mathrm{C}$ in photophase and $22 \pm 1^{\circ} \mathrm{C}$ in scotophase and $70 \pm 5 \%$ relative humidity.

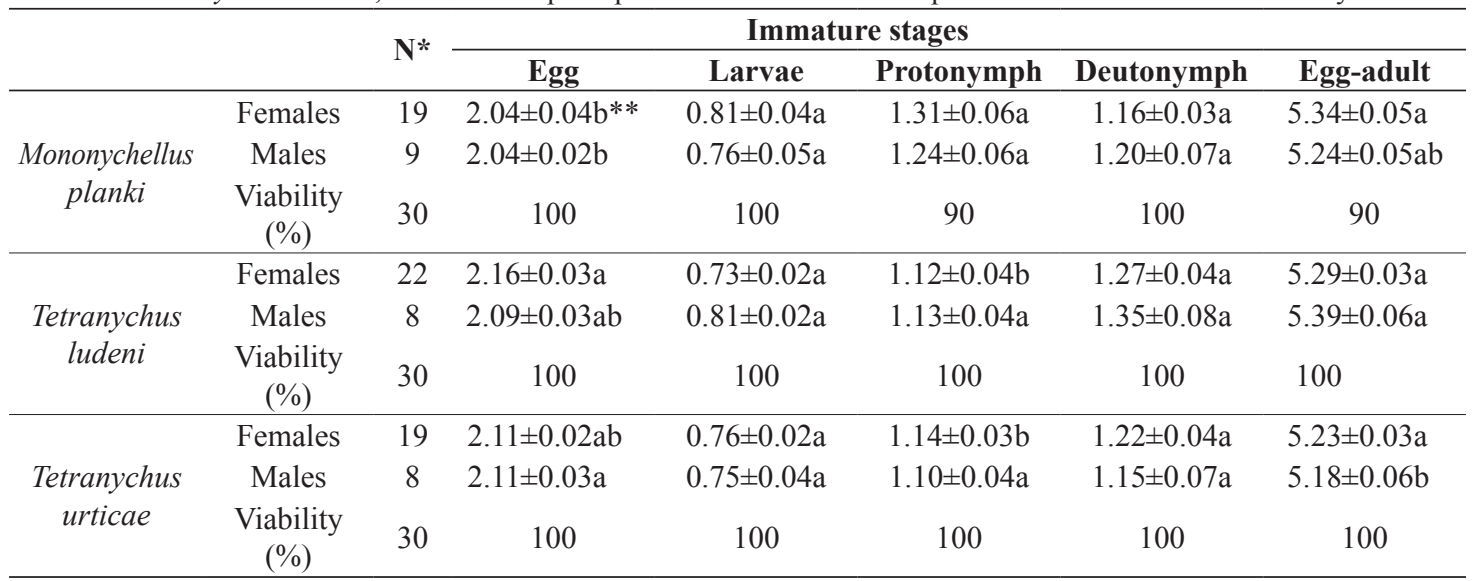

$* \mathrm{~N}=$ number of mites evaluated; **Means followed by the same letter, in a column, do not differ statistically from one another by the Tukey test, at a significance level of $5 \%$.

Table 2. Fertility in days (mean $\pm \mathrm{SE}$ ) and length of pre-oviposition, oviposition, post-oviposition and longevity of Neoseiulus idaeus feeding on Mononychellus planki, Tetranychus ludeni and Tetranychus urticae, at $28 \pm 1^{\circ} \mathrm{C}$ in photophase and $22 \pm 1^{\circ} \mathrm{C}$ in scotophase and $70 \pm 5 \%$ relative humidity.

\begin{tabular}{lcccccc}
\hline \multicolumn{1}{c}{ Parameter } & N* & $\begin{array}{c}\text { Mononychellus } \\
\text { planki }\end{array}$ & N & $\begin{array}{c}\text { Tetranychus } \\
\text { ludeni }\end{array}$ & N & $\begin{array}{c}\text { Tetranychus } \\
\text { urticae }\end{array}$ \\
\hline Fertility & 19 & $4.6 \pm 1.58 \mathrm{~b} * *$ & 22 & $21.8 \pm 3.22 \mathrm{a}$ & 19 & $26.2 \pm 2.41 \mathrm{a}$ \\
Pre-oviposition & 9 & $2.6 \pm 0.86 \mathrm{a}$ & 19 & $1.6 \pm 0.14 \mathrm{~b}$ & 19 & $1.5 \pm 0.11 \mathrm{~b}$ \\
Oviposition & 9 & $6.9 \pm 1.10 \mathrm{~b}$ & 19 & $10.7 \pm 1.16 \mathrm{ab}$ & 19 & $11.7 \pm 3.66 \mathrm{a}$ \\
Post-oviposition & 9 & $1.1 \pm 0.65 \mathrm{a}$ & 19 & $0.5 \pm 0.21 \mathrm{a}$ & 19 & $0.8 \pm 0.27 \mathrm{a}$ \\
Longevity (Females) & 19 & $5.6 \pm 5.49 \mathrm{~b}$ & 19 & $11.3 \pm 1.41 \mathrm{a}$ & 19 & $14.2 \pm 0.86 \mathrm{a}$ \\
Longevity (Males) & 9 & $6.0 \pm 1.51 \mathrm{a}$ & 8 & $13.0 \pm 2.75 \mathrm{a}$ & 8 & $7.0 \pm 2.47 \mathrm{a}$ \\
\hline
\end{tabular}

$* \mathrm{~N}=$ number of mites evaluated; **Means followed by the same letter, in a column, do not differ statistically from one another by the Tukey test, at a significance level of $5 \%$. 
Table 3. Mean generation time $(T)$, net reproductive rate $\left(R_{0}\right)$, innate capacity for increase $\left(R_{m}\right)$ and finite increase rate $(\lambda)$ of Neoseiulus idaeus feeding on Mononychellus planki, Tetranychus ludeni and Tetranychus urticae, at $28 \pm 1^{\circ} \mathrm{C}$ in photophase, $22 \pm 1{ }^{\circ} \mathrm{C}$ in scotophase and $70 \pm 5 \%$ relative humidity.

\begin{tabular}{cccc}
\hline \multirow{2}{*}{ Parameter } & \multicolumn{3}{c}{ Prey } \\
\cline { 2 - 4 } & Mononychellus planki & Tetranychus ludeni & Tetranychus urticae \\
\hline $\mathrm{T}$ & $12.65 \pm 0.14 \mathrm{~b}^{*}$ & $13.94 \pm 0.08 \mathrm{a}$ & $13.82 \pm 0.11 \mathrm{a}$ \\
$\mathrm{R}_{\mathrm{o}}$ & $4.42 \pm 0.49 \mathrm{c}$ & $17.77 \pm 0.55 \mathrm{~b}$ & $20.59 \pm 0.48 \mathrm{a}$ \\
$\mathrm{r}_{\mathrm{m}}$ & $0.09 \pm 0.005 \mathrm{c}$ & $0.20 \pm 0.002 \mathrm{~b}$ & $0.22 \pm 0.001 \mathrm{a}$ \\
$\kappa$ & $1.25 \pm 0.01 \mathrm{c}$ & $1.61 \pm 0.005 \mathrm{~b}$ & $1.66 \pm 0.003 \mathrm{a}$ \\
\hline
\end{tabular}

*Means followed by the same letter, in a column, do not differ statistically from one another by the Tukey test, at a significance level of $5 \%$.

fed on M. planki and higher when such predator mite fed on T. urticae. The finite increase rate $(\lambda)$ was lower with M. planki and higher on T. urticae.

Neoseiulus idaeus presented lower specific fertility and survival rate when fed on $M$. planki whether compared with to other preys, surviving during 22 days (Figure 1). The higher specific fertility occurred during the $10-13^{\circ}$ day, while survival rate was higher during the $8-13^{\circ}$ day.

Neoseiulus idaeus presented lower specific fertility and survival rate when fed on T. ludeni whether compared with T. urticae, surviving during 26 days (Figure 2). The higher specific fertility occurred during the $9-13^{\circ}$ day, while survival rate was higher during the $7-11^{\circ}$ day.

Neoseiulus idaeus presented a higher specific fertility and survival rate when fed on T. urticae whether compared to other preys, surviving during 30 days (Figure 3 ). The higher specific fertility occurred during $9-13^{\circ}$ day, while survival rate was higher during $7-14^{\circ}$ day.

\section{Discussion}

The results obtained on the present study demonstrate that $N$. idaeus populations are able to complete its development feeding on the evaluated preys, in soybean crops of the Norwest portion of Rio Grande do Sul state. The phytophagous mite $M$. planki demonstrated to be a less suitable prey if compared to T. ludeni and T. urticae.

The mean duration of egg-adult stage (days) was higher for $N$. idaeus females which were fed on M. planki and lower for those which were fed on T. urticae. The N. idaeus males presented a higher mean duration of egg-adult stage (days) when fed on T. ludeni and a lower mean duration when fed on T. urticae. Neoseiulus idaeus from Mato Grosso do Sul state, Brazil, feeding on M. tanajoa and T. urticae demonstrated lower mean duration for females when fed on M. tanajoa (3.5 \pm 0.74$)$ and on T. urticae $(4.4 \pm 0.90)$. Regarding the males, such work presented a mean duration of egg-adult stage of $4.1 \pm 0.70$ days when the predator was fed on M. tanajoa and $4.5 \pm 0.86$ days when fed on T. urticae (Moraes et al., 1994). These results indicate that $N$. idaeus population from Northwest of Rio Grande do Sul may live longer when fed on T. ludeni and T. urticae. However, the predator strain or prey-food utilized in the test may influence these results. In addition, these results confirm that species of the genus Mononychellus are less suitable

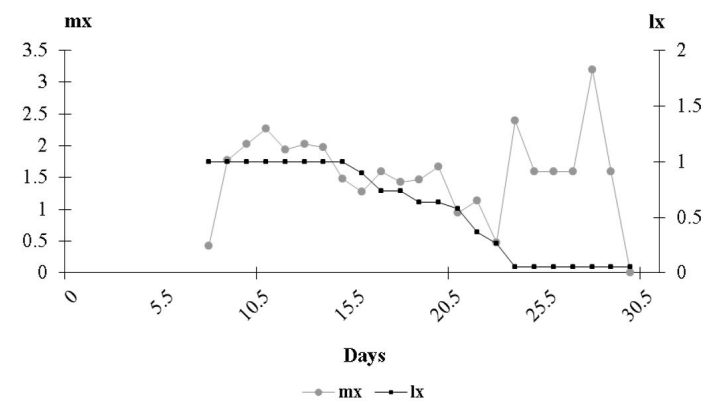

Figure 1. Specific fertility $(\mathrm{mx})$ and survival rate $(\mathrm{lx})$ of Neoseiulus idaeus feeding on Mononychellus planki, at $28 \pm 1{ }^{\circ} \mathrm{C}$ in photophase, $22 \pm 1{ }^{\circ} \mathrm{C}$ in scotophase and $70 \pm 5 \%$ relative humidity.

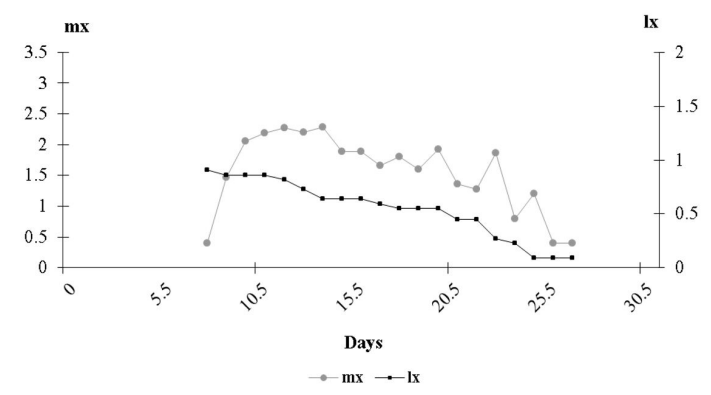

Figure 2. Specific fertility $(\mathrm{mx})$ and survival rate (lx) of Neoseiulus idaeus feeding on Tetranychus ludeni, at $28 \pm 1^{\circ} \mathrm{C}$ in photophase, $22 \pm 1^{\circ} \mathrm{C}$ in scotophase and $70 \pm 5 \%$ relative humidity.

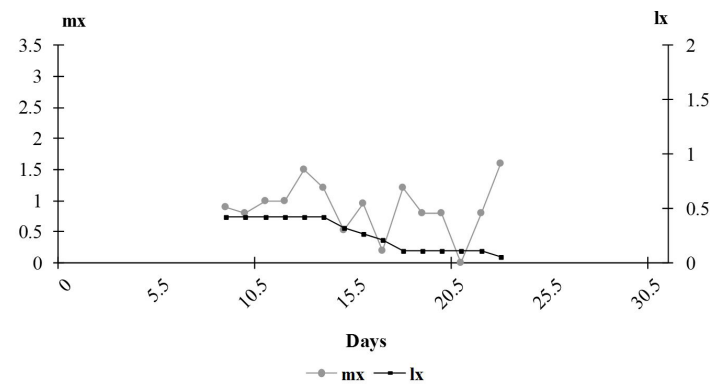

Figure 3. Specific fertility $(\mathrm{mx})$ and survival rate (lx) of Neoseiulus idaeus feeding on Tetranychus urticae, at $28 \pm 1^{\circ} \mathrm{C}$ in photophase, $22 \pm 1^{\circ} \mathrm{C}$ in scotophase and $70 \pm 5 \%$ relative humidity. 
preys to $N$. idaeus than species of the genus Tetranychus, since $M$. tanajoa and M. planki presented lower fitness as prey. Maintained on low relative humidity (55\%) and fed on T. urticae eggs, the evaluation of $N$. idaeus strain from Colombia presented similar results to the this work, with female's length of $4.56 \pm 0.50$ days and male's length of $4.87 \pm 0.34$ days (Dinh et al., 1988). Differently, when $N$. idaeus was fed on eggs and adults T. urticae, inferior results on papaya $(3.8 \pm 0.12)$ and snap bean $(4.0 \pm 0.08)$ were obtained (Collier et al., 2007). These different results may be due to the predator strain, distinct origin or different prey-food. Escudero and Ferragut (2005) observed lower egg-adult phase length testing $N$. californicus fed on T. ludeni (4.67 days). In contrast, when fed on T. urticae, such predator presented greater length (Toldi et al., 2013).

The predator mean fertility was significantly lower when fed on $M$. planki (4.6 \pm 1.58 eggs/female $)$ and higher when fed on T. urticae (26.2 \pm 2.41 eggs/female). Moraes et al. (1994) obtained a high fecundity rate of $N$. idaeus with $M$. tanajoa as food source (11.8 $\pm 7.44 \mathrm{eggs} /$ female) and lower fecundity rate when $N$. idaeus was fed on T. urticae (13.8 \pm 8.85 eggs/female). Escudero and Ferragut (2005) tested $N$. californicus with $T$. ludeni as food source and obtained a lower fecundity rate (2.62 eggs/female). However, Toldi et al. (2013) tested such predator mite fed on T. urticae, and obtained a higher fecundity rate (38.14 \pm 5.58 eggs/female).

In the present study, the longevity of $N$. idaeus females and males was significantly lower with $M$. planki as food source, and higher on T. urticae females and T. ludeni males. Moraes et al. (1994) obtained higher results on M. tanajoa females (9.3 \pm 3.79 days) and lower results on T. urticae (12.1 \pm 6.24 days). In regarding to the males, such work described higher results on M. tanajoa $(9.0 \pm 4.49$ days $)$ and lower results on T. urticae (10.9 \pm 6.59 days).

All life table parameters presented higher values when the predator fed on T. urticae, except the length average of every generation $(\mathrm{T})$, which was higher on T. ludeni and lower on $M$. planki, indicating that the last prey is less adequate to $N$. idaeus.

In the present study, the duration of each generation was longer than that obtained by Moraes et al. (1994) studying M. tanajoa and T. urticae, Dinh et al. (1988) studying T. urticae eggs and Collier et al. (2007) investigating T. urticae eggs and adults. Escudero and Ferragut (2005) studied N. californicus fed on T. ludeni and obtained higher results. Toldi et al. (2013) also obtained higher results when $N$. californicus was fed on T. urticae.

The net reproductive rate $\left(\mathrm{R}_{\mathrm{o}}\right)$ observed was lower for M. planki and higher for T. urtcae. In contrast, Moraes et al. (1994) observed higher $\mathrm{R}_{\mathrm{o}}$ for M. tanajoa and lower $\mathrm{R}_{\mathrm{o}}$ for T. urticae, while Dinh et al. (1988) described a significantly higher $\mathrm{R}_{\mathrm{o}}$ for T. urticae. After Collier et al. (2007), the $\mathrm{R}_{\mathrm{o}}$ was lower when fed on eggs and adults T. urticae. Neoseiulus californicus fed on T. ludeni, presented higher net reproductive rate (Escudero and Ferragut, 2005) than the net reproductive rate presented in this work. However, Toldi et al. (2013) observed a similar result, when such predator was fed on T. urticae.
The innate capacity for increase $\left(\mathrm{r}_{\mathrm{m}}\right)$ obtained in the present study with $N$. idaeus, was lower on $M$. planki $(0.09 \pm 0.005)$ and higher on T. urticae $(0.22 \pm 0.001)$. The $\mathrm{r}_{\mathrm{m}}$ obtained by Moraes et al. (1994) was higher for M. tanajoa and T. urticae. Dinh et al. (1988) observed higher $\mathrm{r}_{\mathrm{m}}$ for T. urticae and Collier et al. (2007) described lower rm when the predator fed on eggs and adults of T. urticae. Escudero and Ferragut (2005), obtained higher results utilizing $N$. californicus feeding on T. ludeni. Toldi et al. (2013) also studied $N$. californicus fed on T. urticae, however they obtained lower results than those presented by Escudero and Ferragut (2005).

Neoseiulus idaeus presented a high increasing population capacity when fed on T. ludeni and T. urticae. This demonstrate that such predator mite belong to type II, as a predator which present an strong aggregation response to leaves infested with Tetranychus species (McMurtry et al., 2013). We also observed that fecundity, net reproductive rate and innate capacity for increase were lower when $N$. idaeus was fed on M. planki, demonstrating that such prey is less adequate. The production of web on leaf circles after the transference of the prey may have favored the predation capacity of T. ludeni and T. urticae. This could partially explain the difference observed in the present study with $M$. planki. Studies have demonstrated that some phytoseiid mites improve its predation rate when reared on leaves infested by tetranychids mites that produce more web (McMurtry et al., 2013). Saito (2010) described the genus Mononychellus as mites which presented LW-f type spin without production of threads and webs, and lay its eggs under dense leaves.

The predator mite $N$. idaeus may be utilized in biological control of T. ludeni, T. urticae. M. planki demonstrated to be an alternative prey that might support the predator development until the adult phase, in quick life cycle with oviposition. However, to be validated, these laboratory results have to be tested at field level. Neoseiulus idaeus can be considered as a potential natural enemy to use in an applied biological control program in soybean crops of Rio Grande do Sul state. However further studies to define release methods, answer to predation and fitness at field level are necessary.

\section{Conclusion}

T. ludeni and T. urticae are suitable prey for N. idaeus while $M$. planki was less adequate as prey. The life table parameters indicate a strong association of $N$. idaeus with prey of the genus Tetranychus. However, N. idaeus reached the adult phase and laid eggs, presenting a quick life cycle when fed only on M. planki.

\section{Acknowledgements}

The authors thank to UNIVATES University Center and Conselho Nacional de Desenvolvimento Científico e Tecnológico $(\mathrm{CNPq})$ for financial support; the anonymous referees for their suggestions and comments that helped to improve the manuscript; Dr. A. Leyva that helped with English editing of the manuscript. 


\section{References}

AYRES, M., AYRES JÚNIOR M., AYRES D.L. and SANTOS, A.A., 2007. BioEstat: aplicações estatísticas nas áreas das ciências biomédicas. Belém: Sociedade Civil Mamirauá. 324 p.

BOLLAND, H.R., GUTIERREZ, J. and FLECHTMANN, C.H.W., 1998. World catalogue of the spider mite family (Acari: Tetranychidae). Leiden: Brill. 392 p.

COLLIER, K.F.S., ALBUQUERQUE, G.S., LIMA, J.O., PALLINI, A. and MOLINA-RUGAMA, A.J., 2007. Neoseiulus idaeus (Acari: Phytoseiidae) as a potential biocontrol agent of the two-spotted spider mite, Tetranychus urticae (Acari: Tetranychidae) in papaya: performance on different prey stage - host plant combinations. Experimental \& Applied Acarology, vol. 41, no. 1-2, pp. 27-36. http://dx.doi.org/10.1007/s10493-006-9041-2. PMid:17237969.

COMPANHIA NACIONAL DE ABASTECIMENTO - CONAB, 2014 [viewed 5 November 2014]. Acompanhamento da safra brasileira de grãos 2013/2014 [online]. Available from: www. conab.gov.br

DINH, N.V., JANSSEN, A. and SABELIS, M.W., 1988. Reproductive success of Amblyseius idaeus and A. anonymus on a diet of twospotted spider mites. Experimental \& Applied Acarology, vol. 4, no. 1, pp. 41-51. http://dx.doi.org/10.1007/BF01213840.

EFRON, B. and TIBSHIRANI, R.J., 1994. An introduction to the bootstrap. Boca Raton: CRC Press.

ESCUDERO, L.A. and FERRAGUT, F., 2005. Life-history of predatory mites Neoseiulus californicus and Phytoseiulus persimilis (Acari: Phytoseiidae) on four spider mite species as prey, with special reference to Tetranychus evansi (Acari: Tetranychidae). BioControl, vol. 32, pp. 378-384. http://dx.doi.org/10.1016/j. biocontrol.2004.12.010

FERLA, N.J. and MORAES, G.J., 2002. Ácaros predadores (Acari) em plantas nativas e cultivadas do Estado do Rio Grande do Sul, Brasil. Revista Brasileira de Zoologia, vol. 19, no. 4, pp. 1011-1031. http://dx.doi.org/10.1590/S0101-81752002000400006.

GUEDES, J.V.C., NAVIA, D., LOFEGO, A.C. and DEQUECH, S.T.B., 2007. Ácaros associados à cultura da soja no Rio Grande do Sul, Brasil. Neotropical Entomology, vol. 32, no. 2, pp. 288293. http://dx.doi.org/10.1590/S1519-566X2007000200017. PMid:17607464.

MAGALHÃES, S. and BAKKER, F.M., 2002. Plant feeding by a predatory mite inhabiting cassava. Experimental \& Applied Acarology, vol. 27, no. 1-2, pp. 27-37. http://dx.doi. org/10.1023/A:1021508620436. PMid:12593510.

MARAFELI, P.P., REIS, P.R., SILVEIRA, E.C., SOUZAPIMENTEL, G.C. and TOLEDO, M.A., 2014. Life history of Neoseiulus californicus (McGregor, 1954)(Acari: Phytoseiidae) fed with castor bean (Ricinus communis L.) pollen in laboratory conditions. Brazilian Journal of Biology = Revista Brasileira de Biologia, vol. 74, no. 3, pp. 691-697. http://dx.doi.org/10.1590/ bjb.2014.0079. PMid:25296220.

MCMURTRY, J.A., MORAES, G.J. and SOURASSOU, N.F., 2013. Revision of the lifestyles of phytoseiid mites (Acari: Phytoseiidae) and implications for biological control strategies. Syst Appl Acarol, vol. 18, no. 4, pp. 297-320. http://dx.doi. org/10.11158/saa.18.4.1.
MORAES, G.J. and FLECHTMANN, C.H.W., 2008. Manual de Acarologia: acarologia básica écaros de plantas cultivadas no Brasil. Ribeirão Preto: Holos Editora. 288 p.

MORAES, G.J., ALENCAR, J.A., WENZEL NETO, F. and MERGULHÃO, S.M.R., 1990. Explorations for natural enemies of the cassava green mite in Brazil. In: HOWELER, R.H., editor. Proceedings of the Eight Symposium of the International Society of Tropical Root Crops, 1990. Bangkok, Thailand. Bangkok: International Society for Tropical Root Crops, pp. 351-353.

MORAES, G.J., MCMURTRY J.A., DENMARK, H.A. and CAMPOS, C.B., 2004. A revised catalog of the mites family Phytoseiidae. Zootaxa, vol. 434, pp. 1-494.

MORAES, G.J., SILVA, C.A.D. and MOREIRA, A.N., 1994. Biology of a strain of Neoseiulus idaeus (Acari: Phytoseiidae) from Southwest Brazil. Experimental \& Applied Acarology, vol. 18, no. 4, pp. 213-220. http://dx.doi.org/10.1007/BF00114168.

REICHERT, M.B., SILVA, G.L., ROCHA, M.S., JOHANN, L. and FERLA, N.J., 2014. Mite fauna (Acari) in soybean agroecosystem in the northwestern region of Rio Grande do Sul State, Brazil. Syst Appl Acarol, vol. 19, no. 2, pp. 123-136. http:// dx.doi.org/10.11158/saa.19.2.2

REZENDE, J.M., LOFEGO, A.C., NUVOLONI, F.M. and NAVIA, D., 2014. Mites from Cerrado fragments and adjacent soybean crops: does the native vegetation help or harm the plantation? Experimental \& Applied Acarology, vol. 64, no. 4, pp. 501-518. http://dx.doi.org/10.1007/s10493-014-9844-5. PMid:25059997.

ROGGIA, S., GUEDES, J.V.C., KUSS, R.C.R., ARNEMANN, J.A. and NÁVIA, D., 2008. Spider mites associated to soybean in Rio Grande do Sul, Brazil. Pesquisa Agropecuaria Brasileira, vol. 43, no. 3, pp. 295-301. http://dx.doi.org/10.1590/S0100204X2008000300002.

SAITO, Y., 2010. Plant mites and sociality: diversity and evolution. Tokyo: Springer. $187 \mathrm{p}$.

SENGONCA, C., KHAN, I.A. and BLAESER, P., 2004. The predatory mite Typhlodromus pyri (Acari: Phytoseiidae) causes feeding scars on leaves and fruits of apple. Experimental \& Applied Acarology, vol. 33, no. 1-2, pp. 45-53. http://dx.doi. org/10.1023/B:APPA.0000029965.47111.f3. PMid:15285137.

SILVA, C.A.D., 2002. Biologia e exigências térmicas do ácarovermelho (Tetranychus ludeni Zacher) em folhas de algodoeiro. Pesquisa Agropecuaria Brasileira, vol. 37, no. 5, pp. 573-580. http://dx.doi.org/10.1590/S0100-204X2002000500001.

SILVA, E.A., REIS, P.R., CARVALHO, T.M.B. and ALTOÉ, B.F., 2009. Tetranychus urticae (Acari: Tetranychidae) on Gerbera jamesonii Bolus and Hook (Asteraceae). Brazilian Journal of Biology $=$ Revista Brasileira de Biologia, vol. 69, no. 4, pp. 1121-1125. http://dx.doi.org/10.1590/S1519-69842009000500016. PMid:19967183

SILVEIRA, S.N., NAKANO, O., BARBIN, D. and NOVA, A.V., 1976. Manual de ecologia e dos insetos. São Paulo: Agronomia Ceres. $419 \mathrm{p}$

TOLDI, M., FERLA, N.J., DAMEDA, C. and MAJOLO, F., 2013. Biology of Neoseiulus californicus feeding on two-spotted spider mite. Biotemas, vol. 26, no. 2, pp. 105-111. http://dx.doi. org/10.5007/2175-7925.2013v26n2p105.

ZHANG, Z., 2003. Mites of greenhouses: identification, biology and control. Cambridge: CABI Publishing. 244 p. 